\title{
Proposal of the Inventory Management Automatic Identification System in the Manufacturing Enterprise Applying the Multi-criteria Analysis Methods
}

https://doi.org/10.1515/eng-2019-0046

Received March 12, 2019; accepted June 5, 2019

\section{Introduction}

Inventory management and warehousing belong to the most extensive fields of logistics in terms of the amount and complexity of developed logistics processes. These fields offer a wide range of options and solutions for their optimization and management approaches. Corporate ability to effectively manage its performance in given areas leads to increase as well as sustain the competitiveness, reduce costs, and hence competitive corporate prices.

The entry of the Czech Republic to the European Union significantly affected the development of logistics as a whole, due to the fact that after the Schengen Agreement, there were significant interconnections and relations of the domestic market with international markets, and the Czech enterprises had to initiate struggling for their customers. An effective logistics has become the key to success.

As already mentioned, the aim of this research study is just to improve some logistics processes in the given enterprise in order to try becoming more competitive.

\section{Description of the Selected Manufacturing Enterprise Activity}

The enterprise, analyzed in this paper, has had a long history. Originally, it was a small enterprise, and today, it is part of a large international corporation, however many processes have not been innovated and developed for many years. Since 2005, the enterprise has experienced long-term growth, but management is aware of some potential threats arising from their own management of the logistics processes. The enterprise offers a wide portfolio of activities in terms of various products handling. Corporate production logistics can be divided into four basic sectors:
*Corresponding Author: Ondrej Stopka: Department of Transport and Logistics, Faculty of Technology, Institute of Technology and Business in České Budějovice, Okružní 517/10, 37001 České Budějovice, Czech Republic, E-mail: stopka@mail.vstecb.cz Mária Stopková: Department of Transport and Logistics, Faculty of Technology, Institute of Technology and Business in České Budějovice, Okružní 517/10, 37001 České Budějovice, Czech Republic, E-mail: stopkova@mail.vstecb.cz

Vladimur Lupták: Department of Transport and Logistics, Faculty of Technology, Institute of Technology and Business in České Budějovice, Okružní 517/10, 37001 České Budějovice, Czech Republic, E-mail: luptak@mail.vstecb.cz 
food packaging, beverage program, gastronomy logistics and foliation activities [1-3].

\section{Implementation of the Specific Equipment Regarding the Automatic Identification of Goods}

The proposal itself deals with the implementing EAN barcode technology, as one of the devices for automatic identification of goods, for clearer and easier inventory management. Specific equipment is identified using multi-criteria analysis, specifically by the TOPSIS and WSA methods. Establishing the warehouse management system applying EAN bar codes nan provide a significant increase in efficiency and clarity of variety of logistics processes, thereby reduce searching (detecting) times for specific pallet units. Currently, the enterprise uses warehouse software which requires updating and programming to allow the displaying the warehouse disposition including all possible positions for storing units. This update is estimated at the cost of $€ 19,455$. In addition, it would be necessary to procure four access points for WIFI coverage of the entire warehouse and production-distribution area. Cost for purchasing one such unit is at $€$ 117. Furthermore, data terminals and printers for production labels need to be purchased as well. The choice of these devices represents the subject of a multi-criteria analysis method procedure [4].

The system is supposed to work so that all received cargo is registered into the system by the data terminal to determine the optimum storage position. A material pallet, as a transport unit, will be located on the particular place and will be paired with a label specifying its position. All the data will be transmitted in real-time mode via WIFI connection into the warehouse software. The data terminal contains several functions, i.e. receipt of goods, its placement, disposal and production $[5,6]$. The software will provide a summary of inventory status information. It is a highly reliable system that greatly simplifies individual activities not only of warehouse employees, but also of store and sales logistics department. Certainly, the software is compatible with the production of warehouse documents (receipt, dispenser etc.). Thus, human error rate is significantly reduced and time required for picking up (or searching for specific pallets) is considerably shortened. Since the enterprise has a staff shortage, it is important to search for some solutions taking into consideration this fact. And in particular such a solution would lead to reduce the number of workers needed [7-11].
Following Table 1 provides a summary of necessary equipment and additional costs to implement a barcode warehouse identification technology.

The number of necessary access points is determined by a real reach of $10,000 \mathrm{~m}^{2}$ in order to cover the whole production and warehouse hall. Both units will be located in two buildings. Five printers will be installed subsequently. The first one will be located in the area of polypropylene and polystyrene manufacture, the second one will be installed in the area of paper products manufacture, the third one will be placed in the area of pulp and duo cup products manufacture and the fourth one will be installed in the pre-production of plastic foils area. The last one is planned to be located in the warehouse office to deal with the repair or replacement operation. Data terminals will be installed in the manufacture area next to each printer so that individual pallets are paired with a given order or a storage option with chosen specific pallet content information. Five more data terminals will be available for warehouse staff [12-14].

Defining the appropriate printer with the data terminal, as important components of the barcode automatic identification technology, is an objective of following multi-criteria analysis process. In order to determine the particular one, the list containing three potential variants associated with the EAN code technology were identified. In regard to the calculation, three different company brands offering their EAN code products, namely Alfa (as variant $\mathrm{V}_{1}$ ), Beta (as variant $\mathrm{V}_{2}$ ) and Gama (as variant $\mathrm{V}_{3}$ ), were selected. The list of individual devices and their parameters, including procurement costs, is indicated in Tables 2-4.

As aforementioned, determining the most appropriate variant is carried out by the particular multi-criteria analysis methods. Specifically, TOPSIS (Technique for Order Preference by Similarity to Ideal Solution) technique and WSA (Weighted Sum Approach) method is applied to obtain the final results [15-19].

\subsection{TOPSIS Method}

Following criteria set was identified to be taken into consideration within calculations:

- $\operatorname{cost}\left(\mathrm{as}_{1}\right)$,

- battery capacity of the data terminal - DT (as $\left.\mathrm{C}_{2}\right)$,

- DT weight (as $\left.\mathrm{C}_{3}\right)$,

- DT resistance to mechanical damage (as $\left.\mathrm{C}_{4}\right)$, - and DT resistance to external influences (as $\mathrm{C}_{5}$ ). 
Table 1: Necessary equipment and additional costs related to the barcode implementation

\begin{tabular}{lccc}
\hline & Price/pcs [€] & Piece quantity & Total price [€] \\
\hline Software update & 19,455 & 1 & 19,455 \\
Access point & 117 & 4 & 468 \\
Data terminal & - & 9 & - \\
Label printer & - & 5 & - \\
Work and other costs & - & - & 778 \\
\hline
\end{tabular}

Source: authors, based on consultation with IT specialist

Table 2: Alfa manufacturer devices and their parameters

\begin{tabular}{|c|c|c|c|}
\hline Devices & $\begin{array}{c}\text { Price/pcs } \\
\text { without VAT [€] }\end{array}$ & $\begin{array}{c}\text { Number of pieces } \\
\text { [pcs] }\end{array}$ & $\begin{array}{c}\text { Total price } \\
\text { without VAT [€] }\end{array}$ \\
\hline Data Terminal & 929 & 9 & 8,361 \\
\hline Printer & 735 & 5 & 3,675 \\
\hline Total & - & - & 12,036 \\
\hline
\end{tabular}

Table 3: Beta manufacturer devices and their parameters

\begin{tabular}{|c|c|c|c|}
\hline Devices & $\begin{array}{c}\text { Price/pcs } \\
\text { without VAT [€] }\end{array}$ & $\begin{array}{c}\text { Number of pieces } \\
\text { [pcs] }\end{array}$ & $\begin{array}{c}\text { Total price } \\
\text { without VAT [€] }\end{array}$ \\
\hline Data Terminal & 1,044 & 9 & 9,396 \\
\hline Printer & 600 & 5 & 3,000 \\
\hline Total & - & - & 12,396 \\
\hline
\end{tabular}

Source: authors

Thus, five criteria were selected in total. Since knowledge of parameters of the EAN code technology accessories is necessary for warehouse staff to be able to practically handle with them, it is very important to determine proper weights of each criterion. Resistance to mechanical damage covers, for example, strike or fall; and resistance to external influences covers, for example, dustiness or humidity [20].

Weights of criteria $\left(\mathrm{w}_{i j}\right)$ are calculated using the Metfessel's method of allocation of 100 points $[19,20]$. The scales of criteria are determined by the corporate management as well as experts in the given field of logistics (subsequently, the arithmetic mean of the individual values was calculated), and are vividly shown in the following summary (see Table 5) [22, 23].

One of the crucial steps of the multi-criteria evaluation of variants is to convert the minimization criteria into maximization (or vice versa; in our case, minimization criteria into maximization). This step is performed in Table 6. The conversion is carried out by subtracting the values for individual cell from the highest value in the column that is being converted [23].
The next step is to transform the table 6 into the criterion matrix $\mathbf{R}=\left(\mathrm{r}_{i j}\right)$, by the formula 1 [23]: 0.040770 .99917

$$
r_{i j}=\frac{y_{i j}}{\sqrt{\sum y_{i j}^{2}}} ; i=1,2, \ldots, m ; j=1,2, \ldots, n
$$

Where:

$\mathrm{r}_{i j}$-criterion matrix elements;

$\mathrm{y}_{i j}$ - Table 6 element values.

$$
\left(\begin{array}{ccccc}
0.04077 & 0.61385 & 0.46429 & 0.60471 & 0.61357 \\
0 & 0.65106 & 0 & 0.60471 & 0.69027 \\
0.99917 & 0.44644 & 0.88568 & 0.51832 & 0.38348
\end{array}\right)
$$

The columns in the R matrix represent the vectors of the unit standard.

Subsequently, it is necessary to determine normalized criterion matrix elements $z_{i j}$ by the formula 2 (to convert the criterion matrix $\mathbf{R}$ into the normalized criterion matrix $\mathbf{Z}$ in such a way that each column of the matrix $\mathrm{R}$ is multiplied by the weight of the corresponding criterion $\left.\left(\mathrm{w}_{i j}\right)\right)$ [24]:

$$
z_{i j}=w_{i j} \cdot r_{i j}
$$


Table 4: Gama manufacturer devices and their parameters

\begin{tabular}{|c|c|c|c|}
\hline Devices & $\begin{array}{c}\text { Price/pcs } \\
\text { without VAT [€] }\end{array}$ & $\begin{array}{c}\text { Number of pieces } \\
\text { [pcs] }\end{array}$ & $\begin{array}{c}\text { Total price } \\
\text { without VAT [€] }\end{array}$ \\
\hline Data Terminal & 296 & 9 & 2,664 \\
\hline Printer & 182 & 5 & 910 \\
\hline Total & - & - & 3,574 \\
\hline
\end{tabular}

Table 5: Introductory matrix for the multi-criteria analysis

\begin{tabular}{|c|c|c|c|c|c|c|}
\hline \multirow[t]{2}{*}{ Variant } & Device & $\begin{array}{c}\mathrm{C}_{1} \\
\text { Price } \\
\text { before VAT }[€]\end{array}$ & $\begin{array}{c}\mathrm{C}_{2} \\
\text { Battery } \\
\text { capacity } \\
\text { [mAh] }\end{array}$ & $\begin{array}{c}\mathrm{C}_{3} \\
\text { Weight } \\
{[\mathrm{g}]}\end{array}$ & $\begin{array}{c}\mathrm{C}_{4} \\
\text { Resistance to } \\
\text { mechanical damage } \\
\text { [scale 1-10] }\end{array}$ & $\begin{array}{c}C_{5} \\
\text { Resistance to external } \\
\text { influences [scale } \\
1-10 \text { ] }\end{array}$ \\
\hline & $\begin{array}{l}\text { nature of the } \\
\text { criterion }\end{array}$ & MIN & MAX & MIN & MAX & MAX \\
\hline $\mathrm{V}_{1}$ & Alfa & 12,036 & 3,300 & 349 & 7 & 8 \\
\hline $\mathrm{V}_{2}$ & Beta & 12,396 & 3,500 & 468 & 7 & 9 \\
\hline \multirow[t]{2}{*}{$V_{3}$} & Gama & 3,574 & 2,400 & 241 & 6 & 5 \\
\hline & riteria weight & 0.3 & 0.3 & 0.1 & 0.1 & 0.2 \\
\hline
\end{tabular}

$$
\left(\begin{array}{ccccc}
0.012 & 0.184 & 0.046 & 0.061 & 0.123 \\
0 & 0.195 & 0 & 0.061 & 0.138 \\
0.299 & 0.134 & 0.089 & 0.052 & 0.077
\end{array}\right)
$$

The next step is to specify the ideal variant (see formula 3: $\mathrm{h}_{j}=\mathrm{h}_{1}, \mathrm{~h}_{2}, \ldots, \mathrm{h}_{n}$ - the highest value for each variant by each criterion) and the basal variant (see formula 4: $\mathrm{d}_{j}=\mathrm{d}_{1}, \mathrm{~d}_{2}, \ldots, \mathrm{d}_{n}-$ the lowest value for each variant by each criterion):

$$
\begin{gathered}
h_{j}=\{0.299 ; 0.195 ; 0.089 ; 0.061 ; 0.138\} ; \\
h_{j}=\max z_{i j} ; j=1,2, \ldots, n \\
d_{j}=\{0 ; 0.134 ; 0 ; 0.052 ; 0.077\} ; \\
d_{j}=\min z_{i j} ; j=1,2, \ldots, n
\end{gathered}
$$

Then, the distance from the ideal variant $d_{i}^{+}$is calculated by the formula 5 [21]:

$$
\begin{aligned}
d_{i}^{+}=\sqrt{\sum_{j=1}^{n}\left(z_{i j}-h_{j}\right)^{2} ; i=1,2, \ldots, m} \\
d_{1}^{+}=0.29079 \\
d_{2}^{+}=0.31196 \\
d_{3}^{+}=0.08674
\end{aligned}
$$

And subsequently, the distance from the basal variant is determined by the formula 6 [24]:

$$
d_{i}^{-}=\sqrt{\sum_{j=1}^{n}\left(z_{i j}-d_{j}\right)^{2} ; i=1,2, \ldots, m}
$$

$$
\begin{aligned}
& d_{1}^{-}=0.08341 \\
& d_{2}^{-}=0.08674 \\
& d_{3}^{-}=0.31197
\end{aligned}
$$

And finally, the indicator of relative distance from basal variant is determined by (formula 7):

$$
C_{i}=\frac{d_{i}^{-}}{d_{i}^{+}+d_{i}^{-}}, i=1,2, \ldots, m
$$

The obtained results are listed in the descending order from the highest calculated value to the lowest one.

$$
\begin{aligned}
& C_{1}=0.2229 \rightarrow \mathbf{2} . \\
& C_{2}=0.2176 \rightarrow \mathbf{3} . \\
& C_{3}=0.7826 \rightarrow \mathbf{1} .
\end{aligned}
$$

Applying the TOPSIS method, variant no. 3 appears to be the best option for implementing in terms of the automatic identification system in particular enterprise, i.e. the Gama device with a recommended printer. Calculated results were significantly affected by the price (procurement costs) of the device. The result is verified by the second technique of the multi-criteria analysis - WSA method, as follows.

\subsection{WSA Method}

Similarly to the TOPSIS technique, the Weighted Sum Approach works predominantly with the weights of individual criteria as well. And again, all the criteria need to be 
Table 6: Conversion of the minimization criteria into maximization

\begin{tabular}{cccccc}
\hline Device & $\mathrm{C}_{1}$ & $\mathrm{C}_{2}$ & $\mathrm{C}_{3}$ & $\mathrm{C}_{4}$ & $\mathrm{C}_{5}$ \\
& MAX & MAX & MAX & MAX & MAX \\
\hline $\mathrm{V}_{1}$ & 360 & 3,300 & 119 & 7 & 8 \\
$\mathrm{~V}_{2}$ & 0 & 3,500 & 0 & 7 & 9 \\
$\mathrm{~V}_{3}$ & 8,822 & 2,400 & 227 & 6 & 5 \\
\hline Criteria weight & 0.3 & 0.3 & 0.1 & 0.1 & 0.2 \\
\hline
\end{tabular}

converted into maximization nature [25-27].

$$
\left(\begin{array}{ccccc}
360 & 3300 & 119 & 7 & 8 \\
0 & 3500 & 0 & 7 & 9 \\
8822 & 2400 & 227 & 6 & 5
\end{array}\right)
$$

After conversion of all the criteria into the maximization character, the first step is to assign each value of the criterion $C_{j}$ its usefulness, i.e. we can create the utility function $\mathrm{u}_{j}$, which for the variant $\mathrm{V}_{i}$ acquires the values of (see formula 8):

$$
u_{j}\left(V_{i}\right)=u_{i j} ; i=1,2, \ldots, m ; j=1,2, \ldots, n
$$

The scope of this function is the interval between the best and the worst value of the relevant criterion. The scope of function values is the interval of $\langle 0,1\rangle$.

After identifying the ideal $\left(h_{j}\right)$ and basal variant $\left(\mathrm{d}_{j}\right)$, it is needed to calculate the partial utility function $\mathrm{u}_{i j}$ of the value $\mathrm{y}_{i j}$ according to the formula 9:

$$
\begin{gathered}
u_{i j}=\frac{y_{i j}-d_{j}}{h_{j}-d_{j}} ; i=1,2, \ldots, m ; j=1,2, \ldots, n \\
\left(\begin{array}{ccccc}
0.041 & 0.818 & 0.524 & 1 & 0.75 \\
0 & 1 & 0 & 1 & 1 \\
1 & 0 & 1 & 0 & 0
\end{array}\right)
\end{gathered}
$$

The weights of criteria remain the same. Total benefit of each variant (aggregate utility function $\mathrm{u}\left(\mathrm{V}_{i}\right)$ ) is calculated by the formula 10 (using the normalized weight of individual criteria $\mathrm{w}_{j}$ ):

$$
u\left(V_{i}\right)=\sum_{j=1}^{n} w_{j} u_{i j}
$$

And finally, we sort individual variants by the values of $\mathrm{u}\left(\mathrm{V}_{i}\right)$. The best option has this value the highest.

$$
\begin{gathered}
u_{1}=0.5601 \rightarrow \mathbf{2} . \\
u_{2}=0.6 \rightarrow \mathbf{1} . \\
u_{3}=0.4 \rightarrow \mathbf{3} .
\end{gathered}
$$

\subsection{Discussion of the Results}

The obtained results of two above performed analyzes are not the same. This is caused due to a different approach to the specific values. While the WSA method primarily calculates the weights of the individual criteria and the ratio of the original values is in the interval of $\langle 01\rangle$, the TOPSIS method covers a deeper context, i.e. it tries to detect an alternative that is at the same time as near to the ideal variant as the farthest basal variant.

Different results are caused by the criterion of procurement cost (specific device price), since the WSA method determines the variant 3 as the best, however it does not address of how much more the variant 3 represents the best alternative. On the contrary, the TOPSIS method is significantly affected by this criterion, due to the fact that there is a big distinction between individual variant values.

In Table 7, the total amount of investments for implementing the barcode identification warehouse system is quantified. Due to the various results obtained from the performed calculations, the investments were quantified for both variants.

Based on the value of difference between the amounts of summary prices totaling $€ 8,822$, above summary table clearly shows relatively strong effect of the price (cost) criterion. The original intention was to calculate the TOPSIS method as a priority, because it solves the problem more complexly. And also, it must be taken into account the fact that the weight of 0.3 was assigned to the price criterion, which represents the highest value assigned. If this criterion is so important, the enterprise should decide on the basis of this criterion and really implement the device Gama (as variant $\mathrm{V}_{3}$ ) for automatic identification of goods as a part of the inventory management [28]. 
Table 7: Comparison of the results by the TOPSIS and WSA method

\begin{tabular}{lcccccc}
\hline & $\begin{array}{c}\text { TOPSIS } \\
\text { Price/pcs } \\
{[€]}\end{array}$ & $\begin{array}{c}\text { Number of pieces } \\
{[\mathrm{pcs}]}\end{array}$ & $\begin{array}{c}\text { Total price } \\
{[€]}\end{array}$ & $\begin{array}{c}\text { Price/pcs } \\
{[€]}\end{array}$ & $\begin{array}{c}\text { WSA } \\
\text { Number of pieces } \\
{[€]}\end{array}$ & $\begin{array}{c}\text { Total price } \\
{[€]}\end{array}$ \\
$\begin{array}{l}\text { Software } \\
\text { update }\end{array}$ & 19,455 & 1 & 19,455 & 19,455 & 1 & 19,455 \\
Access point & 117 & 4 & 468 & 117 & 4 & 468 \\
Data terminal & 296 & 9 & 2,664 & 1,044 & 9 & 9,396 \\
Label printer & 182 & 5 & 910 & 600 & 5 & 3,000 \\
Work and other & - & - & 778 & - & - & 778 \\
costs & - & - & $\mathbf{2 4 , 2 7 5}$ & - & - & $\mathbf{3 3 , 0 9 7}$ \\
Total price & & & Source: authors
\end{tabular}

\section{Conclusion}

The specific equipment in terms of the inventory management automatic identification system, needed for warehousing and manufacture purposes, is specified out of three selected combinations of devices by different manufacturers (company brands). For the final calculation, specific multi-criteria analysis techniques are used. Specifically, the TOPSIS method is applied, and subsequently the results are compared by the WSA method. However, due to the distinct character of both analyzes, no confirmation is performed.

The WSA method establishes a ranking (order) based only on determination which option is to be the best for a given criterion, taking into consideration the weights of criteria. While the TOPSIS method examines the given issue more detailed and solves the distances of individual variants from ideal and basal values. Various results are caused mainly by the considerable difference in device prices, since the criterion of price has assigned its weight at the value of 0.3 , i.e. it is considered the essential criterion.

Acknowledgement: This manuscript was supported within solving the research project entitled "Autonomous mobility in the context of regional development LTC19009" of the INTER-EXCELLENCE program, the VES 19 INTER-COST subprogram.

\section{References}

[1] Droździel, P., Komsta, H. \& Krzywonos, L., An analysis of costs of vehicle repairs in a transportation company. Part I, Transport Problems, 2012, 7, 67-75

[2] Ližbetin, J., Černá, L. \& L'och, M., Model evaluation of suppliers in terms of real company for selected criteria, Nase More, 2015,
62, 147-152

[3] Majerčák, P., Majerčáková, E., Nedeliaková, E., Management of optimization in logistics leads to savings in transport costs, In: Transport Means - Proceedings of the International Conference, (Kaunas, Lithuania), 2014, October 23-24, Kaunas: KAUNAS UNIV TECHNOLOGY PRESS, 364-367

[4] Jerabek, K., Majercak, P., Kliestik, T. \& Valaskova, K., Application of Clark and Wright's savings algorithm model to solve routing problem in supply logistics, Nase More, 2016, 63, 115-119

[5] Majerčák, P., Klieštik, T., Masárová, G., Buc, D. \& Majerčáková, E., System approach of logistic costs optimization solution in supply chain, Nase More, 2013, 60, 95-98

[6] Lorincová, S. Improvement of the Effectiveness in the Recruitment Process in the Slovak Public Administration, In: A. Sujova, . L. Krajcirova (Ed.). Procedia Economics and Finance, (Tech Univ Zvolen, Izmir, TURKEY), 2015, April 30 - May 2, ELSEVIER SCIENCE BV, 382-389

[7] Lizbetinova, L., Hitka, M., Kleymenov, M., Motivational Preferences of Employees in Requirements of Czech and Russian Transport and Logistics Enterprises, Nase More, 2018, 65, 254258

[8] Stacho, Z., Potkany, M., Stachova, K., Marcineková, K., The Organizational Culture as a Support of Innovation Processes' Management: a Case Study, International Journal of Quality Research, 2016, 10, 769-783

[9] Kmecova, I. Analysis of the Efficiency of the Educational Processes of the Subjects Business Management, Human Resource Management, and Mathematics, and their Comparison, In: L.G. Chova, A.L. Martinez, I.C. Torres (Ed.). 12th International Technology, Education and Development Conference (INTED), (Valencia, Spain), 2018, March 5-7, IATED-INT ASSOC TECHNOLOGY EDUCATION \& DEVELOPMENT, 1781-1788

[10] Lizbetinova, L., Hitka, M., Li, Ch., Caha, Z., Motivation of Employees of Transport and Logistics Companies in the Czech Republic and in a Selected Region of the PRC, In: O. Stopka (Ed.). 18th International Scientific Conference on LOGI 2017, (Ceske Budejovice, Czech Republic), 2017, October 19, EDP Sciences, 00032

[11] Houska, M. Reply to the paper 'Multi-criteria analysis of economic activity for European union member states and candidate countries: TOPSIS and WSA applications' by S. E. Dincer, European Journal of Social Sciences, 2012, 30, 290-295 
[12] Houska, M., Domeova, L., Berankova, M. The conversion of cost and benefit criteria in the TOPSIS method, International Journal of Applied Decision Sciences, 2012, 5, 329-341

[13] Nývlt, V., Life cycle costing in BIM management, In: K. Sojkova, J. Tywoniak, A. Lupisek, P. Hajek (Ed.). CESB 2016 - Central Europe towards Sustainable Building 2016: Innovations for Sustainable Future., (Prague, Czech Republic), 2016, Jun 22-24, Grada Publishing, 1438-1444

[14] Kucharcikova, A., Miciak, M., The Application of Human Capital Efficiency Management towards the Increase of Performance and Competitiveness in an Enterprise Operating in the Field of Distribution Logistics, Nase More, 2018, 65, 276-283

[15] Čejka, J., Dobiáš, V., Ludvík, M., Optimisation of the line routing using the multi-criteria evaluation of alternatives, In: D. Szarkova, D. Richtarikova, P. Letavaj, M. Prasilova, (Ed.). 16th Conference on Applied Mathematics, (Bratislava, Slovakia), 2017, January 31 - February 2, Slovak University of Technology in Bratislava, 323-333

[16] Němec, F., Hitka, M., Lorincová, S., Turínská, L. The storage area market in the particular territory, Nase More, 2015, 62, 131-138

[17] Millek, J., The robustness of TOPSIS results using sensitivity analysis based on weight tuning, In: D. Szarkova, D. Richtarikova, P. Letavaj, M. Prasilova (Ed.). IFMBE Proceedings, (Bratislava, Slovakia), 2017, January 31- February 2, Slovak University of Technology in Bratislava, 323-333

[18] Fedorko, G., Molnár, V., Dovica, M., Tóth, T. Conveyor belt quality assessment for in-house logistics, Quality - Access to Success, 2018, 19, 35-38

[19] Török, Á., Fedorko, G., Molnar, V., Husaková, N.,Csiszár, C. How to choose and when to start best ITS projects that enhance logistic performance?, Periodica Polytechnica Transportation Engineering, 2017, 45, 8-11
[20] Binar, T., Svarc, J., Zacal, J., Dostal, P. New Storage System for Engine during Transportation, In: D. Dujak (Ed.). 18th International Scientific Conference on Business Logistics in Modern Management, (Osijek, Croatia), 2018, October 11-12, EKONOMSKI FAKULTET OSIJEKU-FAC ECONOMICS OSIJEK, 73-82

[21] Droździel, P., Wińska, M., Madleňák, R.,Szumski, P. Optimization of the position of the local distribution centre of the regional post logistics network, Transport Problems, 2017, 12, 4350

[22] Kampf, R., Lorincová, S., Hitka, M., Caha, Z. The Application of $A B C$ Analysis to Inventories in the Automatic Industry Utilizing the Cost Saving Effect, Nase More, 2016, 63, 120-125

[23] Pelegrina, G.D., Duarte, L.T., omano, J.M.T. Application of independent component analysis and TOPSIS to deal with dependent criteria in multicriteria decision problems, Expert Systems with Applications, 2019, 122, 262-280

[24] Rashidi, K. \& Cullinane, K. A comparison of fuzzy DEA and fuzzy TOPSIS in sustainable supplier selection: Implications for sourcing strategy, Expert Systems with Applications, 2019, 121, 266-281

[25] Yu, B., Cai, M., Li, Q. A $\lambda$-rough set model and its applications with TOPSIS method to decision making, Knowledge-Based Systems, 2019, 165, 420-431

[26] Gejdos, M., Gergel, T., Jerabek, K., Hrebicek, Z., Optimization of Transport Logistics for Forest Biomass, Nase More, 2018, 65, 246-249

[27] Yu, C., Shao, Y., Wang, K., Zhang, L. A group decision making sustainable supplier selection approach using extended TOPSIS under interval-valued Pythagorean fuzzy environment, Expert Systems with Applications, 2019, 121, 1-17

[28] Richter, L. Inventory and inventory management, Logi - Scientific Journal on Transport and Logistics, 2011, 2, 88-98 